\title{
Global Liver Proteome Analysis Using iTRAQ Reveals AMPK-mTOR-Autophagy Signaling Is Altered by Intrauterine Growth Restriction in Newborn Piglets
}

Baisheng Long, ${ }^{\dagger, \uparrow}$ Cong Yin, ${ }^{\dagger, \ddagger}$ Qiwen Fan, ${ }^{\dagger, \ddagger}$ Guokai Yan, ${ }^{\dagger, \ddagger}$ Zhichang Wang, Xiuzhi Li, ${ }^{\dagger, \star}$ Changqing Chen, ${ }^{\dagger, \ddagger}$ Xingya Yang, ${ }^{\dagger, \ddagger}$ Lu Liu, ${ }^{\dagger, \star}$ Zilong Zheng, ${ }^{\dagger, \star}$ Min Shi, $\uparrow, \$$ and Xianghua Yan ${ }^{\dagger, * * *}$

${ }^{\dagger}$ College of Animal Sciences and Technology, Huazhong Agricultural University, Wuhan, 430070, Hubei, China

${ }^{\sharp}$ The Cooperative Innovation Center for Sustainable Pig Production, Wuhan, 430070, Hubei, China

\begin{tabular}{|l|l|}
\hline Supplementary Table 1 & $\begin{array}{l}\text { The proteins were identified and quantified by LC-MS/MS } \\
\text { strategy in the liver of IUGR newborn piglets }\end{array}$ \\
\hline Supplementary Table 2 & $\begin{array}{l}\text { Significantly altered proteins in the liver of IUGR newborn } \\
\text { piglets }\end{array}$ \\
\hline Supplementary Table 3 & $\begin{array}{l}\text { Functional classification of these } 78 \text { differentially expressed } \\
\text { proteins }\end{array}$ \\
\hline Supplementary Table 4 & $\begin{array}{l}\text { The network analysis of these } 78 \text { differentially expressed } \\
\text { proteins }\end{array}$ \\
\hline Supplementary Table 5 & $\begin{array}{l}\text { The canonical pathway analysis of these } 78 \text { differentially } \\
\text { expressed proteins }\end{array}$ \\
\hline
\end{tabular}

